《醸家銘々伝 $>$

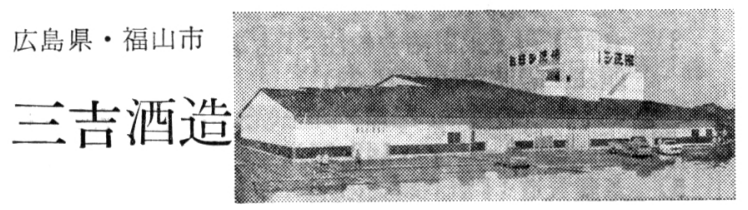

徳川時代, 水野家, 阿部家の城下町として栄えた福山 市は, 明治以後, 織物の産地として又各種産業で栄えた が，昭和 40 年日本鋼管(株)がこの地に工場を建設し一 躍鉄の町として大飛躍をとげた。

当社は, 初代三吉直右衛門が慶応 2 年 (1866) 福山市 の北約 10 キロの広島県深安群下竹田村 (現神辺町) で 焼酎, 清酒の製造を始めたのが酒造業の始まりで，明治 6 年頃政府の免許を受け現在で約 120 年を経過してい る。系図によれば三吉家は, 大職冠鎌足公 13 代の苗裔 藤原朝臣兼忠が東海道安房国より下向, 備後の国富田庄 比咯尾山城主となり, 後三吉安芸守藤原朝臣兼範と改め た。これが三吉家の元祖である。後足利に属し, 又毛利 家の幕下となる等, 幾多の変遷を経て 15 代三吉丹後守 藤原秀央が，下竹田村蟄居した。その後 11 代を経て， 26 代に当る初代三吉直右衛門藤原秀政が，下竹田村で 酒造業を始め (德川末期) 次第に発展した。2 代目三吉 直右衛門（幼名本右衛門，阪大・工・醊酵卒）の時, 当 時理研が試作した合成酒に興味を持ち，同志と語らい， 福山市三吉町に関西酒造(株)を興し, 清酒の外, 新式蒸 溜法による焼酎, 味淋, 合成清酒, ウィスキ一, 合成葡 萄酒等を手掛けた（大正 $7 \sim 8$ 年）。日本各地にも新式 焼酎の工場が出来たが、第一次世界大戦終了と共に経済 界が悪化し，焼酎工場は次々に閉鎖を余儀なくされた。 関西酒造(株)も経営が行きつまり, やむなく借入金を肩 替りした(株)三吉酒造場の福山工場として清酒の製造に 主力を注いた（大正 14 年）。

昭和 5 年 4 月 2 代目三吉直右衛門死亡により，3 代目 三吉直右衛門 (幼名 学, 阪大・工・酘酵卒) が, 下竹 田村は交通不便のため, 竹田工場を福山工場に統合し, 又 昭和 8 年本社も福山一移した（昭和 8 年 4 月 1 日下竹田 郵便局——現竹尋郵便局, 請願創設 々引替に閉鎖す)。 次男誠（広大・工・醱酵卒）も卒業後直らに兄を補佐す ベく入社（昭和 8 年）副社長として今日に至っている。

日本の大陸政策に伴い, 各種企業が大陸へ進出し, 当 社も中支の江蘇省常州で清酒製造の新会社を起し順調に 発展していたが, 内地では人員, 資材の確保のため企業 整備が行なわれ, 清酒工場も約半数が廃業又は保留工場 に指定された。当社は幸いにして操業工場となったが, 戦 局は益々不利となり, 昭和 20 年 8 月 8 日福山市空襲に
より，三吉町本社工場は扊燼に㷌した。又常州工場も当 時の中国通貨 1 億元で接収されたが，名目だけで今だに 全く入金されていない。当時社長（ 3 代目直右衛門）は 応召して, 比島より中支に転戦し不在で, 副社長を中心 に急遽神辺町の整備による休止蔵を借受け操業を続け, 同時に福山工場の復旧を急ぎ, 昭和 22 年秋より福山工 場にて操業を始めた (社長 21 年春復員)。

その後 30 年余, 仮工場ともいらべき福山三吉工場で 操業を続けたが，当時は資材不足の中での建設で不備な 個所も多く, 又古家移築の事とて年数もたち大修理を要 する個所もでき, 又街も繁華となり必ずしも酒造りに最 適の場所とはいいかねる状況に立ち至っていた。そこで 数年前より, 昭和 49 年より専務として入社した社長長 男和重（阪大・工・醱酵卒, 工博）を中心として, 工場 移転の計画を立て, 時間をかけて適地を物色し, 水も空 気も最適で，良好な環境の場所を福山市箕島町茶山に得 て，一昨年暮より工事に着手し，昨昭和 58 年 11 月完 成, 目下茶山工場創業第 2 年目である。

当社の製品については, いわゆる広島酒で, きめ細 く，かるく，飲みあきのしない酒をねらっている。

主たる銘柄は「ミョシ正宗」で片仮名を使った酒名は 全国でもそう多くないが，縁起の良いイメージとして 「ミヨシ」を, 清酒のイメージに相応しい「正宗」と結 びつけている。丁度当家の姓と所の名称福山市三吉町と も一致し，その一連性を通じて品位ある酒のイメージ付 けを意図している。図柄は参議雅経の歌「み吉野の山の 秋風さ夜ふけて….」等の連想より桜を基調とした。

販路については, 戦前は大阪, 福山を主に, 東京, 富 山, 名古屋以西, 山陰, 山陽, 四国, 九州各地へ出荷 し, 現在では福山, 大阪, 名古屋を主に, 東京, 富山, 高松, 岡山, 広島, 山口, 北九州, 福岡等である。

\section{（三吉 誠記・禁転載）}

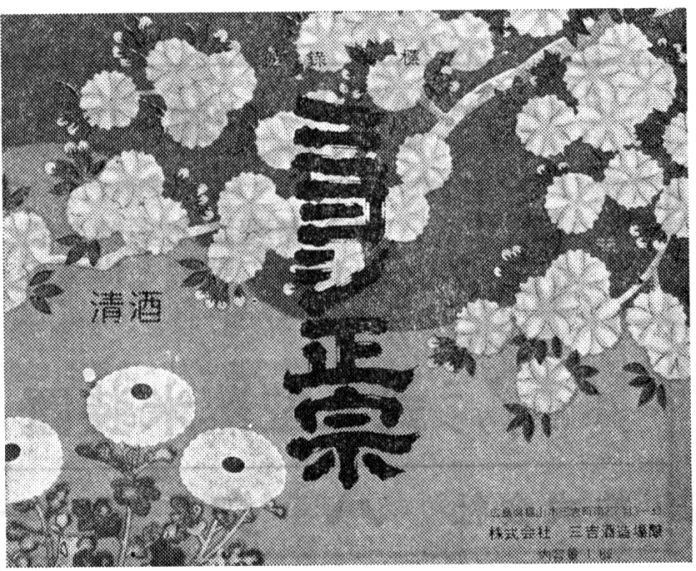

